\title{
КІЛЬКІСНА МОРФОЛОГІЧНА ОЦІНКА ВІКОВОГО РЕМОДЕЛЮВАННЯ ВЕНОЗНОГО РУСЛА ПЕРЕДМІХУРОВОЇ ЗАЛОЗИ
}

\section{Кількісна морфологічна оцінка вікового ремоделювання венозного русла передміхурової залози}

М. С. Гнатюк, С. О. Нестерук, Л. В. Татарчук, Н. Я. Монастирська

Тернопільський національний медичний університет імені І. Я. Горбачевського мОЗ України

Резюме. Відомо, що венозне русло відіграє важливу роль у дренуванні венозної крові від органів. При порушенні вказаної фуннції в органах виникає венозне повнокров'я, що ускладнюється гіпоксією, дистрофрією та некробіозом клітин та тканин. Необхідно вказати, що вікові структурні зміни венозного русла передміхурової залози досліджені недостатньо.

Мета дослідження - за допомогою кількісних морфологічних методів вивчити особливості вікового ремоделювання венозного русла передміхурової залози.

Матеріали і методи. Досліджено венозне русло передміхурової залози 40 лабораторних білих щурівсамців, яких поділили на 2 групи: перша нараховувала 20 інтактних практично здорових тварин віком 8 місяців, які знаходилися у звичайних умовах віварію, друга - 20 білих щурів віком 24 місяці. Евтаназію тварин здійснювали кровопусканням в умовах тіопенталового наркозу. 3 передміхурової залози виготовляли гістологічні мікропрепарати, на яких визначали діаметр закапілярних венул, венул, зовнішній та внутрішній, товщину стінки венозних судин, висоту ендотеліоцитів, діаметри їх ядер, ядерно-цитоплазматичні відношення в цих клітинах, відносні об'єми ушкоджених ендотеліоцитів, щільність мікросудин. Кількісні показники обробляли статистично.

Результати. Морфометрично встановлено, що 3 віком діаметр закапілярних венул передміхурової залози зріс на 7,4 \%, венул - на 6,7\%, зовнішній діаметр венозних судин - на 5,8 \%, внутрішній - на 11,9 \%, відносний об'єм ушкоджених ендотеліоцитів - у 2 рази, товщина стінки вен зменшилася на 8,5 \%, висота ендотеліоцитів - на 3,9 \%, їх ядер - на 4,3\%. Щільність мікросудин та ядерно-цитоплазматичні відношення в ендотеліоцитах не змінювалися, що свідчило про вікову стабільність тканинного та клітинного структурних гомеостазів.

Висновки. Вікова структурна перебудова венозного русла передміхурової залози у лабораторних білих щурів характеризується розширенням венозної ланки
Quantitative morphological evaluation of age remodeling of the venous bed of the prostate

M. S. Hnatjuk, S. O. Nesteruk, L. V. Tatarchuk, N. Ja. Monastyrska

I. Horbachevsky Ternopil National Medical University e-mail: nesterukso@tdmu.edu.ua

Summary. It is known that the venous bed plays an important role in the drainage of venous blood from organs. When this function is impaired, venous plethora develops in the organs, which is complicated by hypoxia, dystrophy and necrobiosis of cells and tissues. It should be noted that agerelated structural changes in the venous bed of the prostate have not been studied enough.

The aim of the study - quantitative morphological methods to study the features of age-related remodeling of the venous bed of the prostate.

Materials and Methods. A set of morphological methods studied the venous bed of the prostate gland of 40 laboratory white male rats, which were divided into 2 groups. Group 1 consisted of 20 intact almost healthy animals aged 8 months, group $2-20$ white rats, aged 24 months. Euthanasia of animals was performed by bloodletting under conditions of thiopental anesthesia. Histological micronutrients were made of the prostate gland, which determined the diameter of capillary venules, venules, external and internal, wall thickness of venous vessels, height of endothelial cells, diameters of their nuclei, nuclear-cytoplasmic ratios in these cells, relative volumes of damaged endotheliocytes. Quantitative indicators were processed statistically.

Results. It was morphometrically established that with age the diameter of capillary venules of the prostate increased by $7.4 \%$, venules - by $6.7 \%$, outer diameter of venous vessels - by $5.8 \%$, inner - by $11.9 \%$, the relative volume of damaged endotheliocytes -2 times the thickness of the vein wall decreased - by $8.5 \%$, the height of endotheliocytes - by $3.9 \%$, their nuclei - by $4.3 \%$. Microvascular density and nuclear-cytoplasmic ratios in endothelial cells did not change, indicating age-related stability of tissue and cellular structural homeostasis.

Conclusions. Age-related structural reconstruction of the venous bed of the prostate in laboratory white rats is characterized by dilation of the venous bed of the hemomicrocirculatory tract, venous vessels, reduction of 
гемомікроциркуляторного русла, венозних судин, зменшенням товщини їх стінок, атрофією ендотеліоцитів, зростанням відносного об'єму ушкоджених ендотеліоцитів при збереженій стабільності клітинного структурного гомеостазу. Ступінь вікової структурної перебудови венозного русла передміхурової залози домінує у закапілярних венулах та венулах.

Ключові слова: передміхурова залоза; венозне русло; вік.

\section{ВСТУП}

Передміхурова залоза - важливий орган чоловічої сечостатевої системи, яка виконує секреторну, бар'єрну функції, бере участь у процесах сечовипускання, сім'явиверження та метаболізмі чоловічих статевих гормонів. Варто зазначити, що на сьогодні дослідники цікавляться структурою та фрункцією передміхурової залози [1-3]. 3 віком ффункціональні можливості передміхурової залози знижуються, що пов'язано з віковими змінами її структур.

Вивчення структури судинного русла, його ангіоархітектоніки в нормі та при різних патологічних станах постійно знаходиться в полі інтересів експериментаторів та клініцистів. Відомо, що венозне русло відіграє важливу роль у дренуванні венозної крові від органів. При порушенні вказаної фрункції в органах виникає венозне повнокров'я, що ускладнюється гіпоксією, дистрофрією та некробіозом клітин та тканин [4]. Необхідно вказати, що вікові структурні зміни венозного русла передміхурової залози досліджені недостатньо.

Метою дослідження було за допомогою кількісних морфологічних методів вивчити особливості вікового ремоделювання венозного русла передміхурової залози.

\section{МАТЕРІАЛИ I МЕТОДИ}

Досліджено венозне русло передміхурової залози 40 лабораторних білих щурів-самців, яких поділили на 2 групи: перша нараховувала 20 інтактних практично здорових тварин віком 8 місяців, які знаходилися у звичайних умовах віварію, друга - 20 білих щурів віком 24 місяці. Евтаназію тварин здійснювали кровопусканням в умовах тіопенталового наркозу. 3 передміхурової залози вирізали шматочки, які фріксували у 10 \% нейтральному розчині фрормаліну, проводили через етилові спирти зростаючої концентрації і поміщали у парафрінові блоки. Мікротомні зрізи товщиною 5-6 мкм після депарафрінізації забарвлювали гематоксиліном та еозином, за ван-Гізон, Маллорі, Вейгертом, Массоном, толуїдиновим синім, проводили імпрегнацію азотокислим сріблом [5].

При морфометрії венозного руслапередміхурової залози визначали діаметр закапілярних венул (ДЗВ), венул (ДВ), зовнішній (ДЗВС) та внутрішній their wall thickness, atrophy of endotheliocytes, increase in the relative volume of damaged endothelial cells. The degree of age structural reconstruction of the venous bed of the prostate dominates in the capillary venules and venules.

Key words: prostate; venous bed; age.

(ДВВС), товщину стінки (ТСВС) венозних судин, висоту ендотеліоцитів (ВЕн), діаметри їх ядер (ДЯЕн), ядерно-цитоплазматичні відношення (ЯЦВЕн) у цих клітинах, відносні об'єми ушкоджених ендотеліоцитів (ВОПЕн), щільність мікросудин на

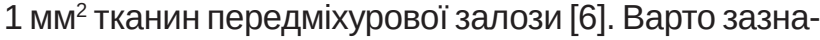
чити, що виконані експериментальні дослідження та евтаназію білих щурів виконували із дотриманням Загальних етичних принципів експериментів на тваринах, ухвалених Першим національним конгресом з біоетики (Київ, 2001) та відповідно до Європейської конвенції про захист хребетних тварин, що використовуються в дослідних та інших наукових цілях [7]

Морфометричні параметри венозних судин обробляли статистично. Обробку результатів виконано у відділі системних ситатистичних досліджень Тернопільського національного медичного університету імені І. Я. Горбачевського МО3 України у програмному пакеті STATISTICA (Stat. Soft. Inc., США). Різницю між порівнювальними морфометричними параметрами визначали за критеріями Стьюдента та Манна - Уїтні [8].

\section{РЕЗУЛЬТАТИ Й ОБГОВОРЕННЯ}

Отримані у результаті проведеного дослідження кількісні морфологічні показники венозного русла передміхурової залози експериментальних тварин різного віку представлені у таблиці 1. Усестороннім аналізом морфометричних параметрів венозного русла передміхурової залози встановлено, що 3 віком майже всі наведені морфометричні параметри змінювалися. Так, діаметр закапілярних венул, з яких починається венозне русло [4, 9], передміхурової залози у 24-місячних щурів статистично достовірно ( $p<0,001)$ збільшився 3 $(12,85 \pm 0,06)$ мкм до $(13,82 \pm 0,09)$ мкм, тобто на $7,4 \%$.

Аналогічно з віком змінювалися діаметри венул передміхурової залози. Вказаний морфометричний параметр у першій групі спостережень дорівнював $(26,90 \pm 0,18)$ мкм, а удругій - $(28,30 \pm 0,21)$ мкм. Між наведеними кількісними морфологічними показниками виявлено виражену статистично достовірну різницю $(p<0,001)$ і останній параметр перевищував попередній на 6,7 \%.

В експериментальних умовах (24-місячні білі щури) зовнішній діаметр венозних судин 
передміхурової залози статистично достовірно ( $p<0,01$ виявився збільшеним на 5,8 \%, внутрішній - на 11,9 \% (p<0,001). При цьому товщина венозної стінки зменшувалася. Так, у 8-місячних експериментальних тварин вказаний морфометричний параметр дорівнював $(12,16 \pm 0,12)$ мкм, а у 24-місячних - $(11,12 \pm 0,12)$ мкм. Наведені кількісні морфологічні показники статистично достовірно $(p<0,001)$ відрізнялися між собою й останній морфометричний параметр виявився меншим за попередній на 8,5 \%.

Кількісним морфологічним аналізом встановалено, що з віком у венозних судинах передміхурової залози виникала атрофрія ендотеліоцитів, що підтверджувалося змінами моророметричних параметрів досліджуваних клітин. При цьому висота ендотеліоцитів із віком зменшилася 3 $(4,85 \pm 0,03)$ мкм до $(4,66 \pm 0,03)$ мкм, тобто на 3,9 \% $(p<0,01)$, а діаметри ядер при цьому знизилися $3(3,50 \pm 0,02)$ мкм до $(3,35 \pm 0,02)$ мкм, тобто на $4,2 \%(p<0,01)$.

Ядерно-цитоплазматичні відношення в ендотеліоцитах венозних судин передміхурової залози 3 віком не змінювалися і дорівнювали у першій

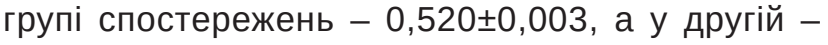
0,518 0,003 (табл.). Встановлене свідчило, що 3 віком в ендотеліоцитах венозного русла структурний клітинний гомеостаз був стабільним [6].

Відносний об'єм ушкоджених ендотеліоцитів венозного русла передміхурової залози з віком 3 вираженим ступенем статистично достовірної різниці $(p<0,001)$ збільшився $3(2,30 \pm 0,02) \%$ до $(4,70 \pm 0,02) \%$, тобто у 2,0 рази. Встановлене вікове зростання ушкоджених ендотеліоцитів у венозному руслі передміхурової залози виникало переважно за рахунок апоптично змінених ендотеліальних клітин. На вікове зростання апоптично змінених клітин вказують також інші дослідники [10]. Варто зазначити, що ушкодження значної кількості дослі- джуваних клітин може призводити до ендотеліальної дисфункції $[11,12]$. При останній порушуються відношення між вазодилататорними та вазоконстрикторними біологічно активними середниками, що синтезуються ендотеліоцитами і які необхідні для регуляції тонусу судин, скоротливості серця, дифузії води, іонів, продуктів метаболізму. Ендотеліальні клітини виконують бар'єрну, синтетичну, гемостатичну, метаболічну, транспортну репаративну фрункції, продукують оксид азоту (NO). Ушкодження значної кількості ендотеліоцитів призводить до їхньої дисорункції, блокади NO-синтази, зменшення синтезу NO, активації процесів його деградації, що супроводжується спазмом та звуженням судин [39]. Останнє погіршує кровопостачання органів, призводить, підтримує та посилює гіпоксію, яка ускладнюється набряком, дистрофрією, некробіозом тканин і клітин $[11,12]$.

Щільність мікросудин у передміхуровій залозі 3

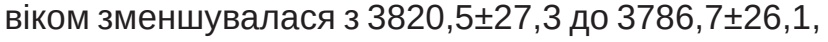
тобто всього на 0,9 \%. Необхідно зазначити, що наведені моророметричні показники статистично достовірно не відрізнялися між собою $(p<0,05)$. Наведені дані дають можливість стверджувати, що 3 віком щільність мікросудин виражено не змінювалася, тобто підтримувалася стабільність тканинного структурного гомеостазу [6] та гемомікроциркуляції [9].

Отримані та проаналізовані у результаті проведеного експерименту дані свідчать, що структура венозного русла передміхурової залози з віком виражено змінюється. Встановлене вікове ремоделювання венозного русла досліджуваного органа характеризується розширенням закапілярних венул та венул, збільшенням зовнішнього та внутрішнього діаметрів венозних судин, стоншенням їх стінки, атрофрією ендотеліоцитів, зменшенням діаметрів їх ядер при збереженому клітинному та тканинному структурному гомеостазі.

Таблиця. Морфометрична характеристика венозного русла передміхурової залози експериментальних тварин $(\mathrm{M} \pm \mathrm{m})$

\begin{tabular}{l|c|c}
\hline \multirow{2}{*}{ Показник } & \multicolumn{2}{|c}{ Група спостереження } \\
\cline { 2 - 3 } & перша & друга \\
\hline ДЗВ, мкм & $12,85 \pm 0,06$ & $13,80 \pm 0,09^{\star \star \star}$ \\
\hline ДВ, мкм & $26,90 \pm 0,18$ & $28,70 \pm 0,21^{\star \star \star}$ \\
\hline ДЗВС, мкм & $40,56 \pm 0,42$ & $42,90 \pm 0,45^{\star \star}$ \\
\hline ДВВС, мкм & $28,40 \pm 0,21$ & $31,78 \pm 0,24^{\star \star *}$ \\
\hline ТСВС, МКм & $12,16 \pm 0,12$ & $11,12 \pm 0,12^{\star \star \star}$ \\
\hline ВЕн, мкм & $4,85 \pm 0,03$ & $4,66 \pm 0,03^{\star \star}$ \\
\hline ДЯЕн, мкм & $3,50 \pm 0,02$ & $3,35 \pm 0,02^{\star \star}$ \\
\hline ЯЦВЕн & $0,520 \pm 0,003$ & $0,518 \pm 0,003$ \\
\hline ВОПЕн, \% & $2,30 \pm 0,02$ & $4,70 \pm 0,02^{\star \star *}$ \\
\hline ЩС & $3820,5 \pm 27,3$ & $3786,7 \pm 26,1$ \\
\hline
\end{tabular}

Примітка. * $-p<0,05 ;{ }^{* *}-p<0,01 ;{ }^{* * *}-p<0,001$.

ISSN 2706-6282(print)

ISSN 2706-6290(online)
Вісник медичних і біологічних досліджень Bulletin of Medical and Biological Research
$4(10), 2021$ 


\section{ВИСновкИ}

Вікова структурна перебудова венозного русла передміхурової залози у лабораторних білих щурів характеризується розширенням венозної ланки гемомікроциркуляторного русла, венозних судин, зменшенням товщини їх стінок, атрофрією ендотелі-

\section{СПИСОК ЛІТЕРАТУРИ}

1. Устенко Р. Л. Стереоморфометрические особенности строения простаты человека и сложности ее номенклатуры / Р. Л. Устенко, О. А. Шерстюк, А. В. Пилюгин // Галицький лікарський вісник. - 2015. - Т. 22, № 3. - С. 111-114.

2. Шепітько В. І. Структурна організація передміхурової залози / В.І.Шепітько, О. В. Вільхова, Ю Р. Согуйко, Р. Р. Согуйко // Вісник проблем біології і медицини. - 2015. - Вип. 4, т. 2 (125). - С. 59-62.

3. Шерстюк О. А. Особенности экстра- и интраорганного кровеносного русла простаты человека / О. А. Шерстюк, Я. А. Тарасенко, А. А. Тихонова // Актуальні питання медичної науки та практики: ДЗ, ЗМАПО МОЗ України, 2015. - Вип. 82 (2). - С. 269-273.

4. Байбаков В. М. Морфофункціональні зміни венозного русла як ланки дренажної системи яєчка при травмуванні судинних анастомозів сім'яного канатика в експерименті / В. М. Байбаков // Клінічна анатомія та оперативна хірургія. - 2011. - Т. 16, № 4. - С. 32-35.

5. Методики морфологічних досліджень / М. М. Багрій, В. А. Діброва, О. Г. Попадинець, І. М. Грищук. - Вінниця : Нова книга, 2016. - 238 с.

6. Автандилов Г. Г. Основы количественной патологической анатомии / Г. Г. Автандилов. - М. : Медицина, 2002. - 240 c.

7. Запорожан В. М. Біоетика і біобезпека / В. М. Запорожан, М. Л. Аряєв. - К. : Здоров'я, 2013. - 456 с.

\section{REFERENCES}

1. Ustenko RL, Sherstyuk O.A., Pilyugin AV. [Stereomorphometric features of the structure of the human prostate and the complexity of its nomenclature]. Halyts med visn. 2015;22(3): 111-4. Ukrainian.

2. Shepitko VI, Vilkhova OV, Soguyko JuR, Soguyko RR. [Structural organization of the prostate]. Bul probl boil i med. 2015;2(125): 59-62. Ukrainian.

3. Sherstyuk OA, Tarasenko JaA, Tikhonova AA.[ Features of extra- and intraorganic bloodstream of the human prostate]. Aktualn pyt med nauk i prakt: DZ, ZMAPO Ministry of Health of Ukraine. 2015: 82 (2);269-273.Ukrainian.

4. Baibakov VM. [Morphofunctional changes of the venous bed as part drainage system of the testis in trauma to the vascular anastomoses of the spermatic cord of the experiment]. Klin anatom i operat v khirur. 2011;16(4): 32-5. Ukrainian.

5. Bagriy MM, Dibrova VA, Popadynets OG, Grishchuk IM. Methods of morphological research. [Методики морфрологічних досліджень] Vinnytsia: Nova knyha; 2016. Ukrainian.

6. Avtandilov GG Fundamentals of quantitative pathological anatomy. [Основы количественной патологической анатомии] Moscow: Meditsina; 2002. Russian. оцитів, зростанням відносного об'єму ушкоджених ендотеліоцитів при збереженій стабільності клітинного структурного гомеостазу. Ступінь вікової структурної перебудови венозного русла передміхурової залози домінує у закапілярних венулах та венулах.

8. Гржибовский А. И. Сравнение количественных данных двух парных выборок с использованием программного обеспечения Statistica и SPSS: параметрические и непараметрические критерии / А. И. Гржибовский, О. В. Иванов, М. А. Горбатова // Наука и здравоохранение. - 2016. - Т. 3. - С. 5-25.

9. Dzhalilova E. A. Ultrastructural organization of rat myocardium and hemomicrocirculatory bed links in norm its reconstruction under experimental streptozotocin - induced diabetes / E. A. Dzhalilova, Vu. Kryvko // Ytalth. - 2013. Vol. 1. - P.115-125.

10. Хламанова Л. І. Морфофрункціональні особливості апоптозу. Проблеми та перспективи застосування апоптозу в сучасній медицині / Л. І. Хламанова, М. Д. Северилова, Ю. В. Ткаченко // Український журнал медицини, біології та спорту. - 2021. - № 2 (4). - С. 185-191.

11. Аксьонов $€$. В. Ендотеліальна диссрункція та шляхи іï профрілактики при проведенні рентгенендоваскулярних процедур по реканалізації коронарних артерій / $€$. В. Аксьонов // Український журнал медицини, біології та спорту. - 2019. - № 5 (21). - С. 105-108.

12. Малярська Н. В. Ендотеліальна дисорункція як універсальний предиктор розвитку серцево-судинної патології та можливості її корекції в практиці сімейних лікарів / Н. В. Малярська, М. А. Калініченко // Ліки України. - 2017. - № 1 (207). - С. 38-41.

7. Zaporozhyan VM, Aryaev ML. Bioethics and biosafety. [Біоетика і біобезпека] Kyiv: Health; 2013. Ukrainian.

8. Grzhibovsky Al, Ivanov OV, Gorbatova MA. [Comparison of quantitative data of two pair samples using the software Statistica and SPSS: parametric and nonparametric criteria]. Nauka i Zdravooh. 2016; 3: 5-25. DOI:1034689/SH/2026.18.3001. Russian.

9. Dzhalilova EA, Kryvko Ju. [Ultrastructural organization of rat myocardium and hemomicrocirculatory bed links in norm its reconstruction under experimental streptozotocin - induced diabetes]. Zdorov. 2013;1: 115-25. Ukrainian.

10. Khlamanova LI, Severilova MD, Tkachenko JuV. [Morphofunctional features of apoptosis. Problems and prospects of apoptosis in modern medicine]. Ukr zhurn med, biol i sport. 2021;2(4): 185-91. Ukrainian.

11. Aksonov EV. [Endothelial dysfunction and ways of its prevention during X-ray endovascular procedures for recanalization of coronary arteries]. Ukr zhurn med, biol i sport. 2019;5(21): 105-8. Ukranian. DOI:10.26.693/ jmbs04.05.109.

12. Malyarska NV, Kalinichenko MA. [Endothelial dysfunction as a universal predictor of cardiovascular pathology and the possibility of its correction in the practice of family physicians]. Liky Ukr. 2017;1(207): 38-41. Ukrainian. Отримано 08.09.21 